\title{
Ignition behaviour of coal and biomass blends under oxy-firing conditions with steam additions
}

Juan Riaza ${ }^{1}$, Lucía Álvarez ${ }^{1}$, María V. Gil ${ }^{1}$, Reza Khatami ${ }^{2}$, Yiannis A. Levendis ${ }^{2}$, José

J. Pis ${ }^{1}$, Covadonga Pevida ${ }^{1}$, Fernando Rubiera ${ }^{1 *}$

${ }^{1}$ Instituto Nacional del Carbón, INCAR-CSIC, Apartado 73, 33080 Oviedo, Spain

${ }^{2}$ Mechanical and Industrial Engineering Department, Northeastern University, Boston, MA, 02115, USA

\section{Abstract}

The ignition behaviour of coal and biomass blends was assessed in air and oxy-firing conditions in an entrained flow reactor. Four coals of different rank, an anthracite, a semianthracite and two high-volatile bituminous coals, were tested in air and $\mathrm{O}_{2} / \mathrm{CO}_{2}$ $\left(21-35 \% \mathrm{O}_{2}\right)$ environments. For all the coals, a deterioration in ignition properties was observed in the $21 \% \mathrm{O}_{2} / 79 \% \mathrm{CO}_{2}$ atmosphere in comparison with air. However, the ignition properties were enhanced when the oxygen concentration in the $\mathrm{O}_{2} / \mathrm{CO}_{2}$ mixture was increased. Coal and biomass blends of a semi-anthracite and a high-volatile bituminous coal with 10 and $20 \mathrm{wt} \%$ of olive residue were also used in the ignition experiments under air and oxy-firing conditions. The ignition behaviour of the coals improved as the additions of biomass increased both in air and oxy-firing conditions. In particular, the effect of biomass blending was more noticeable for the ignition of the high rank coal. Since industrial oxy-coal combustion with a wet recycle would result in higher concentrations of $\mathrm{H}_{2} \mathrm{O}_{(\mathrm{v})}$, the effect of steam addition on ignition behaviour was also studied. A worsening in ignition behaviour was observed when steam was added to

\footnotetext{
* Corresponding author: Tel.: +34 985118 975; Fax: +34 985297662

E-mail address: frubiera@incar.csic.es
} 
the oxy-fuel combustion atmospheres, although an increase in the steam concentration from 10 to $20 \%$ did not produce any significant difference in the ignition characteristics of the fuels.

Keywords: biomass; coal; ignition behaviour; oxy-combustion, steam

\section{Introduction}

The use of coal in power plants generates a large amount of $\mathrm{CO}_{2}$ which is the chief cause of global climate change. A diverse power generation portfolio including Carbon Capture and Storage (CCS) technologies and renewable energies is needed to reduce atmospheric $\mathrm{CO}_{2}$ to below 1990 levels ${ }^{1,2}$. During oxy-coal combustion, coal is burnt in a mixture of oxygen and recycled flue gas (RFG), mainly $\mathrm{CO}_{2}$ and water vapour, to yield a rich $\mathrm{CO}_{2}$ stream, which after purification is ready for sequestration ${ }^{3}$. In addition, biomass is a source of energy which is considered carbon neutral as the carbon dioxide released during its combustion is recycled as an integral part of the carbon cycle. The combination of oxy-coal combustion with biomass co-firing can help to increase $\mathrm{CO}_{2}$ capture efficiency ${ }^{4}$. However, the successful implementation of the oxyfuel technology in pulverised coal boilers depends on fully understanding the differences that may result from replacing $\mathrm{N}_{2}$ with a mixture of $\mathrm{CO}_{2}$ and water vapour in the oxidiser stream. In oxy-firing conditions, due to the higher concentrations of $\mathrm{CO}_{2}$ and $\mathrm{H}_{2} \mathrm{O}_{(\mathrm{v})}$, compared to conventional air combustion, several aspects such as heat transfer, flame ignition, pollutant formation and volatiles and char combustion are affected ${ }^{5-9}$. The use of biomass in existing coal power plants requires only minor modifications compared to 
the construction of new biomass-only fired power plants, making the co-firing of coal and biomass an easy and cheap way to obtain biomass energy ${ }^{10}$.

The application of the oxy-combustion technology has been implemented at a higher scale in Vattenfall's $30 \mathrm{MW}_{\text {th }}$ oxyfuel pilot plant in Schwarze Pumpe, Germany ${ }^{11}$, which was constructed in order to investigate the oxyfuel firing process. The combustion investigations have focused on the radiation heat flux behaviour, $\mathrm{NO}_{x}$ formation, as well as combustion performance and reaction rates between air and oxyfuel operation modes. Details on the operation with three different burners (one combined jet-swirl burner and one swirl burner both from Alstom, and one swirl DSTburner delivered by Hitachi) have been provided and it was found that the operation of the oxyfuel boiler with the three burners tested so far has proven to be very reliable and a good flame ignition and high stability over the entire load range has been achieved ${ }^{12}$. The recycling of flue gas and the injection of the oxygen add more complexity to the design and operation of the oxyfuel burners and boilers ${ }^{13}$. Under oxyfuel conditions, the burner geometry has to be modified in order to achieve a stable flame attached to the burner quarl at oxygen contents in the $\mathrm{O}_{2} / \mathrm{RFG}$ mixture close to that in air. In this regard a series of test runs was performed at the oxycoal test facility at RWTH Aachen University with the aim to achieve an experimentally confirmed database needed for development of a swirl burner able to operate at a wide range of $\mathrm{O}_{2}$ concentrations (from 18 to $34 \%$ vol. $\mathrm{O}_{2}$ ) under oxy-firing conditions. Thus, a new burner concept based on aerodynamic stabilization of an oxyfuel swirl flame has been developed ${ }^{14}$. The ignition of solid fuel particles is an important preliminary step in the overall combustion process due to its influence on the stability, shape and length of the flame, and on the formation of pollutant. In practice, the ignition behaviour of solid fuels may 
be decisive for identifying the optimal location for injecting them into industrial pulverised fuel burners. The ignition and combustion behaviour of pulverised coal particles are not inherent properties of the coals, as they are dependent on the operating conditions $^{15}$. In the oxy-fuel combustion of pulverised coal, poor ignition quality has often been observed during pilot-scale burning trials when operating with substantial flue gas recirculation ${ }^{16}$. Several efforts have been made recently to understand the fundamentals of ignition (i.e., particle ignition, flame propagation and flammability) in oxy-firing conditions when designing combustion systems ${ }^{17,18}$.

The present work studies the influence of fuel type, $\mathrm{CO}_{2}$ dilution and oxygen concentration on the temperature and ignition mechanisms for a wide number of coals and coal/biomass blends (up to $20 \%$ wt biomass). It needs to be appreciated that, when blending different fuels, certain aspects such as ignition behaviour, burnout or NO emissions cannot always be estimated from the behaviour of the individual fuels ${ }^{19}$. As Smart et al. ${ }^{20}$ have pointed out, another important aspect to consider is the effect of wet recycling in oxy-firing conditions on coal ignition and flame stability. In the present work, the effect of adding 10 and $20 \%$ of steam on the ignition characteristics, under air and oxy-firing conditions, was also studied.

\section{Experimental}

\subsection{Materials}

Four coals of different rank were used in this work: an anthracite from Cangas del Narcea, in Asturias, Spain (AC), a semi-anthracite from the Hullera Vasco-Leonesa in León, Spain (HVN), a South African high-volatile bituminous coal from the Aboño power plant in Asturias, Spain (SAB), and a washed coal supplied by the Batán coal 
preparation plant in Asturias, Spain (BA). A biomass, olive residue (OR) was also employed. This biomass is the wet solid residue that remains after the process of pressing and extraction of the olive oil. The coal and biomass samples were ground and sieved to obtain a particle size fraction of $75-150 \mu \mathrm{m}$. The proximate and ultimate analyses together with the high heating values of the samples are presented in Table 1.

\subsection{Experimental device and procedure}

The ignition characteristics of the coals and coal/biomass blends were studied in an entrained flow reactor (EFR), which has been described in detail elsewhere ${ }^{8}$. Briefly, the reactor has a reaction zone $140 \mathrm{~cm}$ in length and an internal diameter of $40 \mathrm{~mm}$. It is electrically heated and is capable of reaching a maximum temperature of $1100{ }^{\circ} \mathrm{C}$. Fuel samples were introduced through a cooled injector before entering the EFR reaction zone. The gases were preheated up to the reactor temperature before being introduced into the EFR, where they passed through two flow straighteners. The reaction products were quenched by aspiration in a stream of nitrogen using a water-cooled probe. The probe was inserted into the reaction chamber from below. Particles were removed by means of a cyclone and a filter. The exhaust gases were monitored using a battery of analysers $\left(\mathrm{O}_{2}, \mathrm{CO}, \mathrm{CO}_{2}, \mathrm{SO}_{2}\right.$, and $\left.\mathrm{NO}\right)$.

During the ignition tests, the reactor was heated at $15^{\circ} \mathrm{C} \mathrm{min}-1$ from 400 to $900{ }^{\circ} \mathrm{C}$. The gas flow used in these tests ensured a particle residence time of $2.5 \mathrm{~s}$. Air $\left(21 \% \mathrm{O}_{2} / 79 \% \mathrm{~N}_{2}\right)$ and three binary mixtures of $\mathrm{O}_{2} / \mathrm{CO}_{2} \quad\left(21 \% \mathrm{O}_{2} / 79 \% \mathrm{CO}_{2}\right.$, $30 \% \mathrm{O}_{2} / 70 \% \mathrm{CO}_{2}$ and $\left.35 \% \mathrm{O}_{2} / 65 \% \mathrm{CO}_{2}\right)$ were employed to study the ignition characteristics of the coals and coal/biomass blends. Also, several ternary mixtures of $\mathrm{O}_{2} / \mathrm{N}_{2} / \mathrm{H}_{2} \mathrm{O}_{\text {(v) }}$ and $\mathrm{O}_{2} / \mathrm{CO}_{2} / \mathrm{H}_{2} \mathrm{O}_{(\mathrm{v})}$ were employed. The addition of 10 and $20 \%$ of steam 
was evaluated for all the air and oxy-fuel combustion atmospheres as a substitute for $\mathrm{N}_{2}$ or $\mathrm{CO}_{2}$ in order to study the effect of the wet recirculation of flue gas on coal ignition properties.

\section{Results and discussion}

\subsection{Effect of the coal rank}

Faúndez et al. ${ }^{21}$ have stated that ignition is characterised by a rapid decrease in CO production, a significant consumption of $\mathrm{O}_{2}$, and an increase in the production of $\mathrm{CO}_{2}$ and NO. Prior to ignition, at low temperatures, the production of $\mathrm{CO}$ increases due to the release of volatiles and incomplete char combustion. The production of $\mathrm{CO}_{2}$ and $\mathrm{NO}$ shows only a slight increase, and there is some $\mathrm{O}_{2}$ consumption due to the evolution and subsequent combustion of coal volatiles at low temperatures. The criterion for determining the ignition temperature was based on the first derivative temperature curves of the gases produced. The ignition temperature was taken as the temperature at which the first derivative curve, normalised from the maximum derivative value, reached an absolute value of $10 \%{ }^{21}$. The ignition temperatures, derived from derivative curves of the gases, for coals AC, HVN, SAB and BA are shown in Table 2. As can be seen, coals $\mathrm{SAB}$ and $\mathrm{BA}$ tend to ignite at lower temperatures than coals $\mathrm{AC}$ and HVN. This may be due to their higher volatiles content (which enhances subsequent char combustion), and to their higher reactivity ${ }^{22}$.

Wall et al. ${ }^{23}$ tracked the changes in gas composition during the ignition of pulverized coal in air in a laboratory scale drop-tube reactor, and associated these changes with the homogeneous ignition of volatiles and heterogeneous char combustion. In general, two types of mechanisms have been observed for coal particle ignition ${ }^{24}$ : gas mode ignition 
(ignition of the volatiles in an enveloping flame that surrounds a devolatilising char particle), heterogeneous mode ignition (which often signifies char ignition) or a combination of both. The ignition mechanism is closely related with the particle combustion mode. In a recent paper by Khatami et al. ${ }^{25}$, the authors employed the term two-mode combustion to signify events where the gas-phase (homogeneous) combustion of volatiles in an enveloping flame that surrounds a char particle, is distinct from the ensuing heterogeneous combustion of the solid char, as it occurs in homogeneous ignition. On the other hand, the term one-mode combustion was used to refer to events where either (i) the combustion of devolatilised char takes place or (ii) the combustion of the volatiles in the proximity of the char surface occurs with, presumably, simultaneous burning of the char occurs, as in heterogeneous ignition. In the present paper, the ignition mode was elucidated from the gas evolution profiles. Examples in the air atmosphere are provided for a better comparison between coal samples.

The evolution of the gases during the ignition tests in air conditions for anthracite coal $\mathrm{AC}$ is shown in Fig. 1. The $\mathrm{CO}$ concentration increases up to a value of $\sim 750 \mathrm{ppm}$. At around $760{ }^{\circ} \mathrm{C}$ there is a reduction in $\mathrm{CO}$ concentration, which is accompanied by a drastic reduction in $\mathrm{O}_{2}$ and a sudden increase in $\mathrm{NO}$ and $\mathrm{CO}_{2}$ corresponding to the ignition of the char. This is confirmed by the continued decrease in $\mathrm{CO}$ after the ignition event. The coal ignites heterogeneously as a result of the direct attack of oxygen on the surface of the char. For the ignition mode of various coal ranks, see also Fig. 2. As can be seen in the cinematographic observations, most of the $\mathrm{AC}$ coal particles burn heterogeneously, there being no evidence of the burning of the volatiles. 
The gas emissions during semi-anthracite coal HVN ignition in air can be seen in Fig. 3. Above $400{ }^{\circ} \mathrm{C}$ there is an increase in the $\mathrm{CO}$ concentration due to coal devolatilisation (the major devolatilisation products are $\mathrm{CH}_{4}, \mathrm{CO}$ and $\mathrm{CO}_{2}$ ). Two changes in the $\mathrm{CO}$ profile and its derivative value can be observed: an initial decrease in $\mathrm{CO}$ concentration takes place at around $625{ }^{\circ} \mathrm{C}$, which corresponds to the combustion of volatiles. The second change involves another decrease in $\mathrm{CO}$ concentration which takes place at around $670{ }^{\circ} \mathrm{C}$. This is accompanied by a sudden decrease in $\mathrm{O}_{2}$ concentration and an increase in $\mathrm{NO}$ and $\mathrm{CO}_{2}$. These latter events correspond to char ignition, which is confirmed by the constant increase in the $\mathrm{CO}_{2}$ produced after the ignition event. This coal presents the most difficult mechanism to be elucidated, i.e., it seems to be homogenous since the ignition of volatiles and char took place sequentially. Coal HVN is a physical blend of approx. $90 \%$ anthracitic and $10 \%$ low volatile bituminous coal from the same mine. For the ignition mode of semi-anthracite HVN coal, see also Figure 2. As observed in the cinematographic records, some of the semi-anthracite HVN particles burn heterogeneously, but for other particles a small surrounding flame is observed corresponding to the combustion of volatiles. This enveloping flame burns up prior to the heterogeneous combustion of the char. However, in the EFR it is not possible to appreciate the ignition of single particles, it can only be seen that, in global, the stream of HVN particles burned homogenously (although much less volatile matter was released in comparison with hvb coals, see Fig 4).

The gas evolution profiles for the SAB ignition tests in air are shown in Fig 4. Above $400{ }^{\circ} \mathrm{C}$ there is a significant increase in $\mathrm{CO}$ concentration (due to the higher volatile matter content of $\mathrm{SAB}$, the amount of $\mathrm{CO}$ released is much higher than for anthracitic coals). Also a continuous decrease in $\mathrm{O}_{2}$ concentration is observed, which suggests that 
part of the volatiles released are oxidised. At a temperature of $530^{\circ} \mathrm{C}$ the $\mathrm{CO}$ concentration starts to decrease, which suggests that coal devolatilisation has ended, and that more $\mathrm{CO}$ is being consumed than formed. From Fig. 4 it can be inferred that the ignition of the char takes place at around $545^{\circ} \mathrm{C}$ (i.e., there is a sudden decrease in the concentration of $\mathrm{CO}$ and $\mathrm{O}_{2}$, and an increase in $\mathrm{NO}$ and $\mathrm{CO}_{2}$ ). This suggests that the ignition of high-volatile coals takes place via a homogeneous mechanism, with the sequential ignition of volatiles and char. However, the ignition delay between the extinction of the volatiles and char combustion is much shorter than in the case of semianthracite coal HVN. For the ignition mode of bituminous coal SAB, see also Figure 2. As can be seen from the cinematographic records, the combustion of coal SAB includes particle devolatilisation with ignition and combustion of the volatiles in a flame that surrounds the particle, followed by the ignition and combustion of the resulting char.

Coal BA is a high-volatile bituminous coal whose ignition mechanism is also homogeneous. Since its gas evolution profiles are very similar to those of coal SAB, they are not shown in this paper.

\subsection{Effect of the $\mathrm{O}_{2} / \mathrm{CO}_{2}$ atmosphere}

In order to evaluate the effect of the presence of $\mathrm{CO}_{2}$ in large concentrations, ignition tests were conducted in both $\mathrm{O}_{2} / \mathrm{N}_{2}$ and $\mathrm{O}_{2} / \mathrm{CO}_{2}$ environments. As can be seen in Table 2 higher ignition temperatures are required when $\mathrm{N}_{2}\left(21 \% \mathrm{O}_{2} / 79 \% \mathrm{~N}_{2}\right)$ is replaced by $\mathrm{CO}_{2}\left(21 \% \mathrm{O}_{2} / 79 \% \mathrm{CO}_{2}\right)$. Stivers et al. ${ }^{26}$ and Khatami et al. ${ }^{27}$ observed a delay in ignition in an $\mathrm{O}_{2} / \mathrm{CO}_{2}$ environment compared to an $\mathrm{O}_{2} / \mathrm{N}_{2}$ environment with identical $\mathrm{O}_{2}$ concentration. They attributed the longer ignition delay partly to the effect of the volumetric heat capacity of the gas mixtures. The temperature rise during ignition is 
inversely proportional to the heat capacity of the surrounding gas and, since the heat capacity of $\mathrm{CO}_{2}$ is higher than that of $\mathrm{N}_{2}$, a reduction in gas temperature occurs. However, the heat capacity and temperature of the surrounding gas are not the only factors that affect ignition properties; the oxygen concentration, the heating rate of the gas and devolatilisation rates of particles, and the coal volatiles content also have a considerable influence ${ }^{15,25}$.

It should be noted that in this study the highest increase in ignition temperature was observed for coal BA, the coal with the highest volatile matter content, due to the lower mass diffusivity of the volatiles in the $\mathrm{CO}_{2}$ mixture ${ }^{28}$. It can also be observed that for semi-anthracite and bituminous coals HVN, SAB and BA and for oxygen concentrations up to $30 \%$ or $35 \%$, the ignition temperature is lower than in air, even though the heat capacity of the gas atmospheres with $\mathrm{O}_{2}$ concentrations up to $30-35 \%$ are still higher than the heat capacity of the air. In the case of anthracite coal AC -which has the lowest volatile matter content- increasing the oxygen concentration to $35 \%$ was not enough to compensate for the negative effects of $\mathrm{CO}_{2}$ on ignition temperature.

From the values of the ignition temperatures it is difficult to determine whether the worsening of the ignition properties under oxy-fuel conditions is due to the reactions affecting the char, the reactions involving the volatiles, changes in heat transfer or a combination of all three factors. For this reason the ignition mechanism of the different coals was inferred from the evolution curves of the gases.

The gas evolution during the ignition of anthracite coal $\mathrm{AC}$ in two of the oxy-firing conditions studied $\left(21 \% \mathrm{O}_{2} / 79 \% \mathrm{CO}_{2}\right.$ and $\left.35 \% \mathrm{O}_{2} / 65 \% \mathrm{CO}_{2}\right)$ is shown in Fig. 5. The ignition mechanism is the same as that observed under air-firing conditions; i.e., the char ignites heterogeneously due to the direct attack of oxygen. The only difference 
between the air and oxy-fuel atmospheres is the larger amount of $\mathrm{CO}$ formed, which may be attributed to char- $\mathrm{CO}_{2}$ reactions. Pyrolysis experiments for the coals studied in the $\mathrm{N}_{2}$ and $\mathrm{CO}_{2}$ atmospheres at $1000{ }^{\circ} \mathrm{C}$ have been carried out previously in the $\mathrm{EFR}^{22}$. The results for volatile yields are presented in Table 3, and they show that the volatile yield is enhanced in a $\mathrm{CO}_{2}$ atmosphere, as the $\mathrm{CO}_{2}$ reacts with the resulting chars. The high amounts of $\mathrm{CO}$ which persist as a thick protective sheath, even with oxygen contents of $35 \%$, prevent particle ignition.

The gas evolution profiles for semi-anthracite coal HVN in oxy-fuel conditions are shown in Fig. 6. An increase in CO concentration occurs due to the devolatilisation of $\mathrm{HVN}$ at temperatures above $400{ }^{\circ} \mathrm{C}$. In the $21 \% \mathrm{O}_{2} / 79 \% \mathrm{CO}_{2}$ atmosphere the combustion of part of these volatiles takes place above $625^{\circ} \mathrm{C}$, as in air-firing conditions. The ignition of the char (i.e, a marked reduction in $\mathrm{O}_{2}$ concentration and a marked increase in $\mathrm{CO}_{2}$ and $\mathrm{NO}$ ) occurs at around $725^{\circ} \mathrm{C}$. The ignition mechanism is the same as that of air ignition. However, higher $\mathrm{CO}$ concentrations are obtained. These higher $\mathrm{CO}$ concentrations contribute to the deterioration in ignition properties, via the formation of a persistent cloud around the particle that prevents the oxygen from gaining access to the surface of the particle. As other authors have observed ${ }^{25,29}$ in a $21 \% \mathrm{O}_{2} / 79 \% \mathrm{CO}_{2}$ atmosphere, the volatiles released remain partially unburnt and form a thick cloud of volatiles. Also, higher concentrations of $\mathrm{CO}$ are formed, partly due to the incomplete combustion of the volatiles, and partly as a result of char gasification by $\mathrm{CO}_{2}$. To compare the intensity and brightness of the burning coal particles in air and $\mathrm{CO}_{2}$ atmospheres see also Figure 2. From the cinematographic records, when $\mathrm{N}_{2}$ is replaced by $\mathrm{CO}_{2}$ for the same oxygen concentration, the burning particles appeared $\operatorname{dim}$ and blurry, which is indicative of slow oxidation. The brightness and intensity of the coal 
combustion increases drastically with oxygen in the $\mathrm{O}_{2} / \mathrm{CO}_{2}$ environments. However, the combustion images of the $30 \% \mathrm{O}_{2} / 70 \% \mathrm{CO}_{2}$ atmosphere resemble those of air.

Since the gas evolution profiles corresponding to $30 \% \mathrm{O}_{2} / 70 \% \mathrm{CO}_{2}$ and $35 \% \mathrm{O}_{2} / 65 \% \mathrm{CO}_{2}$ are similar, only those for the $35 \% \mathrm{O}_{2} / 65 \% \mathrm{CO}_{2}$ atmosphere are shown in Fig. 6. At temperatures above $400{ }^{\circ} \mathrm{C}$ the process of coal devolatilisation starts with the consequent increase in $\mathrm{CO}$ concentration. As in the case of the $\mathrm{N}_{2}$ and $\mathrm{CO}_{2}$ atmospheres with a $21 \%$ oxygen content, the $\mathrm{CO}$ starts to oxidize above $625^{\circ} \mathrm{C}$. The ignition of the char occurs at $642{ }^{\circ} \mathrm{C}$. Thus, in these cases ignition also takes place with the sequential ignition of volatiles and char. However, the time delay between volatiles and char combustion decreases as the oxygen concentration increases and ignition occurs at a lower temperature than in air. Khatami et al. ${ }^{25,27}$ have also observed that the ignition delay in $\mathrm{O}_{2} / \mathrm{CO}_{2}$ atmospheres becomes smaller as $\mathrm{O}_{2}$ increases. The ignition and combustion of volatiles provide extra heat that enhances the ignition of the char. However, this effect is not observed for coal AC due to its low volatile matter content. Also, when there is sufficient oxygen, the combustion of $\mathrm{CO}$ to form $\mathrm{CO}_{2}$ provides extra heat.

The gas evolution of bituminous coal $\mathrm{SAB}$ during its ignition in oxy-firing conditions is shown in Fig. 7. High amounts of $\mathrm{CO}$ are released during coal devolatilisation, which are later oxidised at temperatures of around $545^{\circ} \mathrm{C}$. Subsequently, char ignition takes place. The ignition mechanism is therefore homogeneous with the sequential ignition of volatiles and chars. However, the time delay between them is much shorter than in the case of semi-anthracite coal HVN, and becomes even shorter with increasing oxygen concentrations. Also larger amounts of $\mathrm{CO}$ are produced under oxy-firing conditions. It can be observed in Table 3 that the volatile yield in $\mathrm{CO}_{2}$ for coal SAB is much higher 
than in $\mathrm{N}_{2}$ in comparison with coals $\mathrm{AC}$ and HVN. These findings are in accordance with those reported by Zhang et al. ${ }^{29}$ who have found that the replacement of $\mathrm{N}_{2}$ by $\mathrm{CO}_{2}$ enhanced coal particle pyrolysis prior to ignition, as $\mathrm{CO}_{2}$ reacted with the resulting char to form additional combustible gases, i.e., $\mathrm{CO}$, in the vicinity of the particle. The cinematographic records showed an increase in both char and volatile burning times in the $21 \% \mathrm{O}_{2} / 79 \% \mathrm{CO}_{2}$ atmosphere in comparison with air-firing conditions. Also, there is a decrease on burning times in the $\mathrm{O}_{2} / \mathrm{CO}_{2}$ environments with increasing oxygen concentrations, and a decrease in the time delay between the extinction of the volatiles and char ignition.

Bituminous coal BA experiences the highest ignition delay, when $\mathrm{N}_{2}$ is replaced by $\mathrm{CO}_{2}$ for the same oxygen concentration, of all the coals under study. As for coal SAB, during its ignition in $21 \% \mathrm{O}_{2} / 79 \% \mathrm{CO}_{2}$, the $\mathrm{CO}$ concentration remains very high over a wide range of temperatures, preventing the oxygen from gaining access to the surface of the particle and causing a big delay in ignition. In a recent paper by Khatami et al. ${ }^{27}$ the authors observed coal and char particle ignition in $\mathrm{O}_{2} / \mathrm{N}_{2}$ and $\mathrm{O}_{2} / \mathrm{CO}_{2}$ atmospheres and found that in a $\mathrm{N}_{2}$ atmosphere the presence of volatiles accelerated the ignition process, as the coals ignited faster than the chars, whereas in $\mathrm{CO}_{2}$ the chars ignited faster than the coals, because the presence of a thick cloud of volatiles appeared to have impeded the ignition process. In the present study, coal BA has the highest content of volatiles, and therefore it will release more $\mathrm{CO}$ than the other coals. Also, as can be seen from Table 3, it shows the highest volatile yield in a $\mathrm{CO}_{2}$ atmosphere (not shown). When the oxygen concentration is increased to $30 \%$ or $35 \%$ the oxidation of $\mathrm{CO}$ to $\mathrm{CO}_{2}$ is favoured and, as a consequence, ignition takes place at lower temperatures. 


\subsection{Effect of the addition of biomass}

The effect of blending coals and biomass on ignition behaviour was studied under air and $\mathrm{O}_{2} / \mathrm{CO}_{2}\left(21-35 \% \mathrm{O}_{2}\right)$ conditions. Two coals of different rank, the semianthracite HVN and the high volatile bituminous coal SAB, were blended with the olive residue OR. The ignition temperatures are shown in Table 4. It can be observed that the addition of olive residue, OR, causes a significant reduction in the ignition temperature of both coals in all the atmospheres studied. This decrease is proportional to the amount of biomass in the blend and is more pronounced for the HVN-OR blends.

As can be seen in Fig 8, the ignition mechanism of the HVN-OR blends in air is homogeneous (i.e., with the sequential ignition of char and volatiles). For the case of oxy-fuel combustion, the addition of biomass does not affect the ignition mechanism because it remains homogeneous, so their gas evolution profiles are not shown in this paper.

In any case, a significant reduction in ignition temperature is observed in both the air and oxy-fuel atmospheres when coal is blended with biomass. Biomass is a highly reactive fuel and has a much higher volatile matter content than coal. The biomass OR will release far more volatiles when it is devolatilised than coal $\mathrm{HVN}$, and this is reflected in the higher $\mathrm{CO}$ concentrations observed in the coal/biomass blends. As mentioned before, the ignition of the volatiles and char takes place sequentially. For coal HVN the ignition of the volatiles occurs at around $600{ }^{\circ} \mathrm{C}$ (see Fig. 3), whereas for blends $90 \mathrm{HVN}-10 \mathrm{OR}$ and $80 \mathrm{HVN}-20 \mathrm{OR}$ it takes place at around $530{ }^{\circ} \mathrm{C}$ and $510{ }^{\circ} \mathrm{C}$, respectively; whereas the combustion of char occurs at $636^{\circ} \mathrm{C}$ and $575^{\circ} \mathrm{C}$. In summary, the addition of increasing quantities of biomass leads to a reduction in the ignition temperatures and in the delay between the ignition of the volatiles and char. 
From Fig. 9 it can be seen that the ignition mechanism of the SAB-OR blends in air is homogeneous, as in the case of the individual coal SAB. The ignition mechanism for oxy-fuel conditions is also homogeneous (figures not shown). Furthermore ignition occurs at lower temperatures as the biomass content in the blends increases. For coal SAB the volatiles ignite at around $530{ }^{\circ} \mathrm{C}$ and the char at $543{ }^{\circ} \mathrm{C}$ (see Fig. 4); whereas for blend 90SAB-10OR the ignition temperatures are of $500{ }^{\circ} \mathrm{C}$ and $510{ }^{\circ} \mathrm{C}$, respectively. In the case of blend $80 \mathrm{SAB}-20 \mathrm{OR}$ there is a marked reduction in ignition delay between the volatiles and char ignition almost to the point where they seem to happen simultaneously at around $461{ }^{\circ} \mathrm{C}$.

Although there is a decrease in ignition temperatures for both char and volatiles when increasing the biomass percentage in the SAB-OR blends, these decreases are less influenced by the addition of biomass than in the case of HVN-OR blends. This suggests that the effect of the addition of biomass on the ignition temperature of coal is more marked for high rank coals. When two fuels are fired as a blend, the ignition properties of the blend may be different to those exhibited when each component is ignited individually ${ }^{30}$. The ignition properties of high rank coals, which have far fewer volatiles and are less reactive than low rank coals, will be more easily enhanced by the addition of biomass. Faúndez et al. ${ }^{19}$ have observed that, when blending fuels with different volatile matter contents, the ignition of the higher volatile component of the blend enhances the ignition of the lower volatile component. However, when both fuels have similar volatile contents, they compete for the oxygen available. As was shown by Khatami et al. ${ }^{25}$ when biomass particles are burned, large volatile flames are formed. This also happens when burning low rank coals. The simultaneous burning of biomass and low rank coals leads to a competition for oxygen and in some zones oxygen 
depletion will result. Consequently, the enhancement of ignition properties will be less marked than when biomass is blended with high rank coals.

In summary, the ignition mechanism of high rank and low rank coals does not change when they are blended with biomass (up to $20 \%$ by mass). However, the addition of biomass improves their ignition properties, i.e., the coal and biomass blends ignite at lower temperatures than the individual coals.

\subsection{Effect of the addition of steam}

In order to study the effect of wet recirculation of flue gas, ignition tests were performed under air and oxy-firing conditions with the addition of steam as a substitute for $\mathrm{N}_{2}$ or $\mathrm{CO}_{2}$, respectively. Two coals of different rank, a semianthracite (HVN) and a high volatile bituminous coal (BA), were chosen for the ignition experiments. The ignition temperatures are shown in Table 5. The partial replacement of $\mathrm{N}_{2}$ or $\mathrm{CO}_{2}$ by steam causes a slight increase in the ignition temperatures, but no significant differences are observed between the results for 10 and $20 \%$ of steam. It should be noted that in the case of coal BA no significant differences were observed when steam was added to the oxy-fuel atmosphere with 30 or $35 \%$ oxygen content.

Fig. 10 shows the gas evolution curves during the ignition of coal HVN under air and oxy-firing conditions with $20 \%$ steam addition. Similar gas evolution curves were obtained for $10 \%$ steam addition (not shown). The addition of steam does not affect the ignition mechanism of coal HVN. However, higher CO concentrations are observed with the addition of water vapour. In the atmospheres with a lower oxygen content (21\%), the CO concentrations are higher and they remain higher over a wider range of temperatures. The reasons for these high $\mathrm{CO}$ concentrations with the addition of steam 
are not yet clear. They may be partly due to unburnt volatiles. Binner et al. ${ }^{31,32}$ observed that the ignition of a volatile flame was delayed during wet coal combustion, as well as a decrease in particle temperature. The same authors also observed that steam gasification of the char could take place to some extent. As was observed for oxy-firing conditions without the addition of steam, the $\mathrm{CO}$ preferentially remains in the vicinity of the particle surface, forming a thick protective sheath. If the $\mathrm{CO}$ remains on the char surface for a long time, this will result in $\mathrm{O}_{2}$ depletion on the char surface, delaying the ignition process. When the oxygen concentration is increased, the combustion of $\mathrm{CO}$ to form $\mathrm{CO}_{2}$ is favoured and, the ignition of the coal particles is enhanced.

A similar conclusion can be drawn from the evolution of gases during the ignition of coal BA in air and oxy-firing conditions with steam addition. The ignition mechanism remains homogeneous for air and oxy-fuel conditions, both in wet and dry conditions. Also higher $\mathrm{CO}$ concentrations are observed with increasing steam addition.

\section{Conclusions}

The aim of this work was to study the ignition characteristics of coal and biomass blends in oxy-firing conditions with and without steam addition. The most important conclusions of this work are as follows:

(a) A significant increase in ignition temperature was observed when $\mathrm{N}_{2}$ was replaced by $\mathrm{CO}_{2}$, for the same oxygen concentration for the four coals studied (an anthracite, a semi-anthracite and two high-volatile bituminous coals). This increase is not only due to the higher heat capacity of the background gas, but also due to the persistence of a thick cloud of volatiles around each particle which prevents its ignition. Not all the coals are affected in the same way by the 
background gases. In the $\mathrm{O}_{2} / \mathrm{CO}_{2}$ with low oxygen content (i.e., 21\%) coals with a higher volatile matter content experience higher ignition delays due to the larger concentrations of volatiles and $\mathrm{CO}$ formed around the particle. The anthracite coal ignites in a heterogeneous mode in both air and oxy-firing conditions, semi-anthracite coal partially ignite heterogeneously whereas the bituminous coals ignite in a homogeneous mode.

(b) Co-firing coal (a semi-anthracite and a high-volatile bituminous coal) and biomass results in an improvement in the ignition properties of the blend in both air and oxy-firing conditions. However, this improvement is more significant in the case of the blends with the semi-anthracite. The ignition properties of the bituminous coal seem to be less affected by the addition of biomass.

(c) A worsening of ignition properties is observed when $\mathrm{N}_{2}$ or $\mathrm{CO}_{2}$ is partially replaced by $\mathrm{H}_{2} \mathrm{O}_{\text {(v) }}$ for both semi-anthracite and high-volatile bituminous coals. Higher $\mathrm{CO}$ concentrations are observed when the $\mathrm{H}_{2} \mathrm{O}_{(\mathrm{v})}$ concentrations are increased. The effect of steam addition is less noticeable in atmospheres with a high oxygen content.

\section{Acknowledgements}

This work was carried out with financial support from the Spanish MICINN (Project PS-120000-2005-2) co-financed by the European Regional Development Fund. L.A. and M.V.G. acknowledge funding from the CSIC JAE programs, co-financed by the European Social Fund. J.R. acknowledges funding from the Government of the Principado de Asturias (Severo Ochoa program), respectively. Support from the CSIC (PIE 201080E09) is gratefully acknowledged. 


\section{References}

1. IEA, World Energy Outlook, 2011.

2. Rubiera F and Pevida C, Progress in pilot, large-scale projects as an inducement for CCUS deployment. Greenhouse Gases: Sci Technol 3. 97-98 (2013)

3. Wall T, Liu Y, Spero C, Elliott L, Khare S, Rathnam R et al, An overview on oxyfuel coal combustion-State of the air research and technology development. Chem Eng Res Des 87: 1003-1016 (2009).

4. Wall TF, Stanger R and Santos S, Demonstrations of coal-fired oxy-fuel technology for carbon capture and storage and issues with commercial deployment. Int Greenhouse Gas Control 5S: S5-S15 (2011).

5. Smart JP, Patel R and Riley GS, Oxy-fuel combustion of coal and biomass, the effect on radiative and convective heat transfer and burnout. Combust Flame 157: 2230-2240 (2010).

6. Shaddix CR and Molina A, Fundamental investigation of NOx formation during oxy-fuel combustion of pulverized coal. Proc Combust Inst 33: 1723-1730 (2011).

7. Álvarez L, Riaza J, Gil MV, Pevida C, Pis JJ and Rubiera F, NO emissions in oxy-coal combustion with the addition of steam in an entrained flow reactor. Greenhouse Gases: Sci Technol 1: 180-190 (2011).

8. Riaza J, Álvarez L, Gil MV, Pevida C, Rubiera F and Pis JJ, Effect of oxy-fuel combustion with steam addition on coal ignition and burnout in an entrained flow reactor. Energy 36: 5314-5319 (2011).

9. Andersen J, Rasmussen CL, Giselsson T and Glarborg P, Global combustion mechanisms for use in CFD modeling under oxy-fuel conditions. Energy Fuel 23: 1379-1389 (2009).

10. Demirbas A, Potential applications of renewable energy sources, biomass combustion problems in boiler power systems and combustion related to environmental issues. Prog Energy Combust Sci 31: 171-192 (2005).

11. Anheden M, Burchhardt U, Ecke H, Faber R, Jidinger O, Giering $\mathrm{R}$ et al, Overview of Operational Experience and Results from Test Activities in Vattenfall's $30 \mathrm{MW}_{\text {th }}$ Oxyfuel Pilot Plant in Schwarze Pumpe. Energy Procedia 4: 941-950 (2011).

12. Rehfeldt S, Kuhr C, Schiffer F-P, Weckes P, Bergins C, First test results of Oxyfuel combustion with Hitachi's DST-burner at Vattenfall's 30 MWth Pilot Plant at Schwarze Pumpe. Energy Procedia 4: 1002-1009 (2011).

13. IEAGHG. Oxyfuel combustion of pulverized coal. 2010/07. August, 2010.

14. Habermehl M, Erfurth J, Toporov D, Förster M, Kneer R, Experimental and numerical investigations on a swirl oxycoal flame. Applied Thermal Engineering 49: 161-169 (2012).

15. Chen L, Yong SZ and Ghoniem AF, Oxy-fuel combustion of pulverized coal: Characterization, fundamentals, stabilization and CFD modelling. Prog Energy Combust Sci 38: 156-214 (2012).

16. Strömberg L, Lindgren G, Jacoby J, Giering R, Anheden M, Burchhardt U et al, Update on Vattenfall's 30 MWth oxyfuel pilot plant in Schwarze Pumpe. Energy Procedia 1: 581-589 (2009).

17. Taniguchi M, Shibata $\mathrm{T}$ and Kobayashi H, Prediction of lean flammability limit and flame propagation velocity for oxy-fuel fired pulverized coal combustion. Proc Combust Inst 33: 3391-3398 (2011). 
18. Taniguchi M, Yamamoto K, Okazaki T, Rehfeldt S and Kuhr C, Application of lean flammability limit and large eddy simulation to burner development for an oxy-fuel combustion system. Int J Greenhouse Gas Control 5S: S111-S119 (2011).

19. Faúndez J, Arias B, Rubiera F, Arenillas A, García X, Gordon AL and Pis JJ, Ignition characteristics of coal blends in an entrained flow reactor. Fuel 86: 20762080 (2007).

20. Smart JP, O'Nions P and Riley GS, Radiative and convective heat transfer, and burnout in oxy-coal combustion. Fuel 89: 833-840 (2010).

21. Faúndez J, Arenillas A, Rubiera F, García X, Gordon AL and Pis JJ, Ignition behaviour of different rank coals in an entrained flow reactor. Fuel 84: 2172-2177 (2005).

22. Gil MV, Riaza J, Álvarez L, Pevida C, Pis JJ and Rubiera F, Oxy-fuel combustion kinetics and morphology of coal chars obtained in $\mathrm{N}_{2}$ and $\mathrm{CO}_{2}$ atmospheres in an entrained flow reactor. Appl Energy 91: 67-74 (2012).

23. Wall TF, Phong-Anant D, VS Gururajan, Wibberley LJ, Tate A and Lucas J, Indicators of ignition for clouds of pulverized coal. Combust Flame 72: 111-118 (1988).

24. Essenhigh RH, MK Misra and Shaw DW, Ignition of coal particles: a review. Combust Flame 77: 3-30 (1989).

25. Khatami R, Stivers C, Joshi K, Levendis YA and Sarofim AF, Combustion behavior of single particles from three different coal ranks and from sugar cane bagasse in $\mathrm{O}_{2} / \mathrm{N}_{2}$ and $\mathrm{O}_{2} / \mathrm{CO}_{2}$ atmospheres. Combust Flame 159: 1253-1271 (2012).

26. Stivers $C$ and Levendis $Y A$, Ignition of single coal particles in $\mathrm{O}_{2} / \mathrm{N}_{2} / \mathrm{CO}_{2}$ atmospheres. In: The $35^{\text {th }}$ international technical conference on clean coal $\&$ fuel systems. Clearwater, Florida, 2010.

27. Khatami R, Stivers $\mathrm{C}$ and Levendis YA, Ignition characteristics of single coal particles from three different ranks in $\mathrm{O}_{2} / \mathrm{N}_{2}$ and $\mathrm{O}_{2} / \mathrm{CO}_{2}$ atmospheres. Combust Flame 159: 3554-3568 (2012).

28. Shaddix CR and Molina A, Ignition and devolatilisation of pulverized coal during oxygen/carbon dioxide coal combustion. Proceedings of the Combustion Institute 32: 2091-2098 (2009).

29. Zhang L, Binner E, Qiao Y and Li C-Z, In situ diagnostics of Victorian brown coal combustion in $\mathrm{O}_{2} / \mathrm{N}_{2}$ and $\mathrm{O}_{2} / \mathrm{CO}_{2}$ mixtures in a drop tube furnace. Fuel 89: 2703-2712 (2010).

30. Arias B, Pevida C, Rubiera F and Pis JJ, Effect of biomass blending on coal ignition and burnout during oxy-fuel combustion. Fuel 87: 2753-2759 (2008).

31. Binner E, Zhang L, Li C-Z and Bhattacharya S, In-situ observation of the combustion of air-dried and wet Victorian brown coal. Proc Combust Inst 33: 1739-1746 (2011).

32. Binner E, Zhang L and Bhattacharya S, Investigation of the effect of inherent water content on the combustion characteristics of Victorian brown coal in air an under oxy-fuel conditions, $26^{\text {th }}$ International Pittsburgh Coal Conference. Pittsburgh, USA, 2009. 
Table 1. Proximate and ultimate analyses and high heating value of the fuel samples

\begin{tabular}{lccccc}
\hline Sample & AC & HVN & SAB & BA & OR \\
\hline \hline $\begin{array}{l}\text { Origin } \\
\text { Rank }\end{array}$ & $\begin{array}{c}\text { Spain } \\
\text { an }\end{array}$ & $\begin{array}{c}\text { Spain } \\
\text { sa }\end{array}$ & $\begin{array}{c}\text { S. Africa } \\
\text { hvb }\end{array}$ & $\begin{array}{c}\text { Spain } \\
\text { hvb }\end{array}$ & $\begin{array}{c}\text { Spain } \\
\text { Proximate Analysis (wt.\%, db) }\end{array}$ \\
\hline Ash & 14.2 & 10.7 & 15.0 & 6.9 & 7.6 \\
V.M. & 3.6 & 9.2 & 29.9 & 33.9 & 71.9 \\
F.C. & 82.2 & 80.1 & 55.1 & 59.2 & 20.5 \\
Ultimate Analysis (wt.\%, daf) & & & & & \\
\hline $\mathrm{C}$ & 94.7 & 91.7 & 81.5 & 88.5 & 54.3 \\
$\mathrm{H}$ & 1.6 & 3.5 & 5.0 & 5.5 & 6.6 \\
$\mathrm{~N}$ & 1.0 & 1.9 & 2.1 & 1.9 & 1.9 \\
$\mathrm{~S}$ & 0.7 & 1.6 & 0.9 & 1.1 & 0.2 \\
$\mathrm{O}^{\text {a }}$ & 2.0 & 1.3 & 10.5 & 3.0 & 37.0 \\
\hline High heating value $\left(\mathrm{MJ} \mathrm{kg}^{-1}, \mathrm{db}\right)$ & 29.2 & 31.8 & 27.8 & 33.1 & 19.9 \\
\hline
\end{tabular}

an: anthracite; sa: semi-anthracite; hvb: high-volatile bituminous coal $\mathrm{db}$ : dry basis; daf: dry and ash free bases

${ }^{\mathrm{a}}$ Calculated by difference 
Table 2. Ignition temperatures $\left({ }^{\circ} \mathrm{C}\right)$ of coals $\mathrm{AC}, \mathrm{HVN}, \mathrm{SAB}$ and $\mathrm{BA}$ under air and $\mathrm{O}_{2} / \mathrm{CO}_{2}\left(21-35\right.$ vol. $\left.\% \mathrm{O}_{2}\right)$

\begin{tabular}{ccccc} 
Coal & $21 \% \mathrm{O}_{2} / 79 \% \mathrm{~N}_{2}$ & $21 \% \mathrm{O}_{2} / 79 \% \mathrm{CO}_{2}$ & $30 \% \mathrm{O}_{2} / 70 \% \mathrm{CO}_{2}$ & $35 \% \mathrm{O}_{2} / 65 \% \mathrm{CO}_{2}$ \\
\hline $\mathrm{AC}$ & 757 & 782 & 767 & 761 \\
$\mathrm{HVN}$ & 700 & 723 & 669 & 642 \\
$\mathrm{SAB}$ & 543 & 565 & 524 & 498 \\
$\mathrm{BA}$ & 509 & 554 & 498 & 490 \\
\hline
\end{tabular}


Table 3. Experimental devolatilisation yields at $1000{ }^{\circ} \mathrm{C}$ in the EFR under $\mathrm{N}_{2}$ and $\mathrm{CO}_{2}$ atmospheres

\begin{tabular}{ccc}
\hline Coal & Volatile yield- $\mathrm{N}_{2}$ & Volatile yield- $\mathrm{CO}_{2}$ \\
\hline \hline AC & 3.6 & 4.2 \\
HVN. & 6.0 & 7.2 \\
SAB & 44.9 & 53.1 \\
BA & 49.9 & 62.2 \\
\hline
\end{tabular}


Table 4. Ignition temperatures $\left({ }^{\circ} \mathrm{C}\right)$ for blends $\mathrm{HVN}-\mathrm{OR}$ and $\mathrm{SAB}-\mathrm{OR}$ in air and $\mathrm{O}_{2} / \mathrm{CO}_{2}$ (21-35 vol. $\left.\% \mathrm{O}_{2}\right)$

\begin{tabular}{ccccc}
\hline & $21 \% \mathrm{O}_{2} / 79 \% \mathrm{~N}_{2}$ & $21 \% \mathrm{O}_{2} / \mathrm{CO}_{2}$ & $30 \% \mathrm{O}_{2} / \mathrm{CO}_{2}$ & $35 \% \mathrm{O}_{2} / \mathrm{CO}_{2}$ \\
\hline \hline HVN & 700 & 723 & 669 & 642 \\
90HVN-10OR & 636 & 662 & 615 & 567 \\
80HVN-20OR & 574 & 612 & 551 & 503 \\
\hline SAB & 543 & 565 & 524 & 498 \\
90SAB-10OR & 510 & 532 & 491 & 455 \\
90SAB-20OR & 461 & 478 & 444 & 425 \\
\hline
\end{tabular}


Table 5. Ignition temperatures $\left({ }^{\circ} \mathrm{C}\right)$ for coals $\mathrm{HVN}$ and $\mathrm{BA}$ in air and $\mathrm{O}_{2} / \mathrm{CO}_{2}(21-35$ vol. $\% \mathrm{O}_{2}$ ) with steam addition (the $\mathrm{H}_{2} \mathrm{O}_{(\mathrm{v})}$ is added as a substitute of $\mathrm{N}_{2}$ or $\mathrm{CO}_{2}$ )

\begin{tabular}{ccccc}
\hline & $21 \% \mathrm{O}_{2} / \mathrm{N}_{2}$ & $21 \% \mathrm{O}_{2} / \mathrm{CO}_{2}$ & $30 \% \mathrm{O}_{2} / \mathrm{CO}_{2}$ & $35 \% \mathrm{O}_{2} / \mathrm{CO}_{2}$ \\
\hline \hline $\mathrm{HVN}$ & 700 & 723 & 669 & 642 \\
$\mathrm{HVN}+10 \% \mathrm{H}_{2} \mathrm{O}_{(\mathrm{v})}$ & 713 & 733 & 682 & 657 \\
$\mathrm{HVN}+20 \% \mathrm{H}_{2} \mathrm{O}_{(\mathrm{v})}$ & 703 & 730 & 678 & 656 \\
\hline $\mathrm{BA}$ & 509 & 554 & 498 & 490 \\
$\mathrm{BA}+10 \% \mathrm{H}_{2} \mathrm{O}_{(\mathrm{v})}$ & 529 & 560 & 499 & 491 \\
$\mathrm{BA}+20 \% \mathrm{H}_{2} \mathrm{O}_{(\mathrm{v})}$ & 548 & 566 & 498 & 492 \\
\hline
\end{tabular}




\section{Figure captions}

Fig 1. Gas emissions and normalised derivative curves of gas concentration during ignition tests in air for anthracite coal AC.

Fig 2. High-speed, high-magnification cinematographic images of single particles (75$150 \mu \mathrm{m}$ ) of various coals (anthracite AC, semi-anthracite HVN, and two bituminous SAB and BA) and a biomass (olive residue OR) in air and in two different simulated oxy-fuel conditions $\left(21 \% \mathrm{O}_{2}-79 \mathrm{CO}_{2}\right.$ and $\left.30 \% \mathrm{O}_{2}-70 \% \mathrm{CO}_{2}\right)$. In each case, a particle is shown prior and after ignition takes place. Different coal ranks experience different ignition modes.

Fig 3. Gas emissions and normalised derivative curves of gas concentration during ignition tests in air for semi-anthracite coal HVN.

Fig 4. Gas emissions and normalised derivative curves of gas concentration during ignition tests in air for bituminous coal SAB.

Fig 5. Gas emissions and normalised derivative curves of gas concentration during ignition tests in oxy-firing conditions for anthracite coal AC.

Fig 6. Gas emissions and normalised derivative curves of gas concentration during ignition tests in oxy-firing conditions for semi-anthracite coal HVN.

Fig 7. Gas emissions and normalised derivative curves of gas concentration during ignition tests in oxy-firing conditions for bituminous coal SAB.

Fig 8. Gas emissions and normalised derivative curves of gas concentration during ignition tests in air-firing conditions for blends HVN-OR. 
Fig 9. Gas emissions and normalised derivative curves of gas concentration during ignition tests in air-firing conditions for blends SAB-OR.

Fig 10. Gas emissions and normalised derivative curves of gas concentration during ignition tests for semi-anthracite coal $\mathrm{HVN}$ in air and $\mathrm{O}_{2} / \mathrm{CO}_{2}\left(21-35 \% \mathrm{O}_{2}\right)$ with steam addition (the $\mathrm{H}_{2} \mathrm{O}_{\text {(v) }}$ is added as a substitute of $\mathrm{N}_{2}$ or $\mathrm{CO}_{2}$ ). 

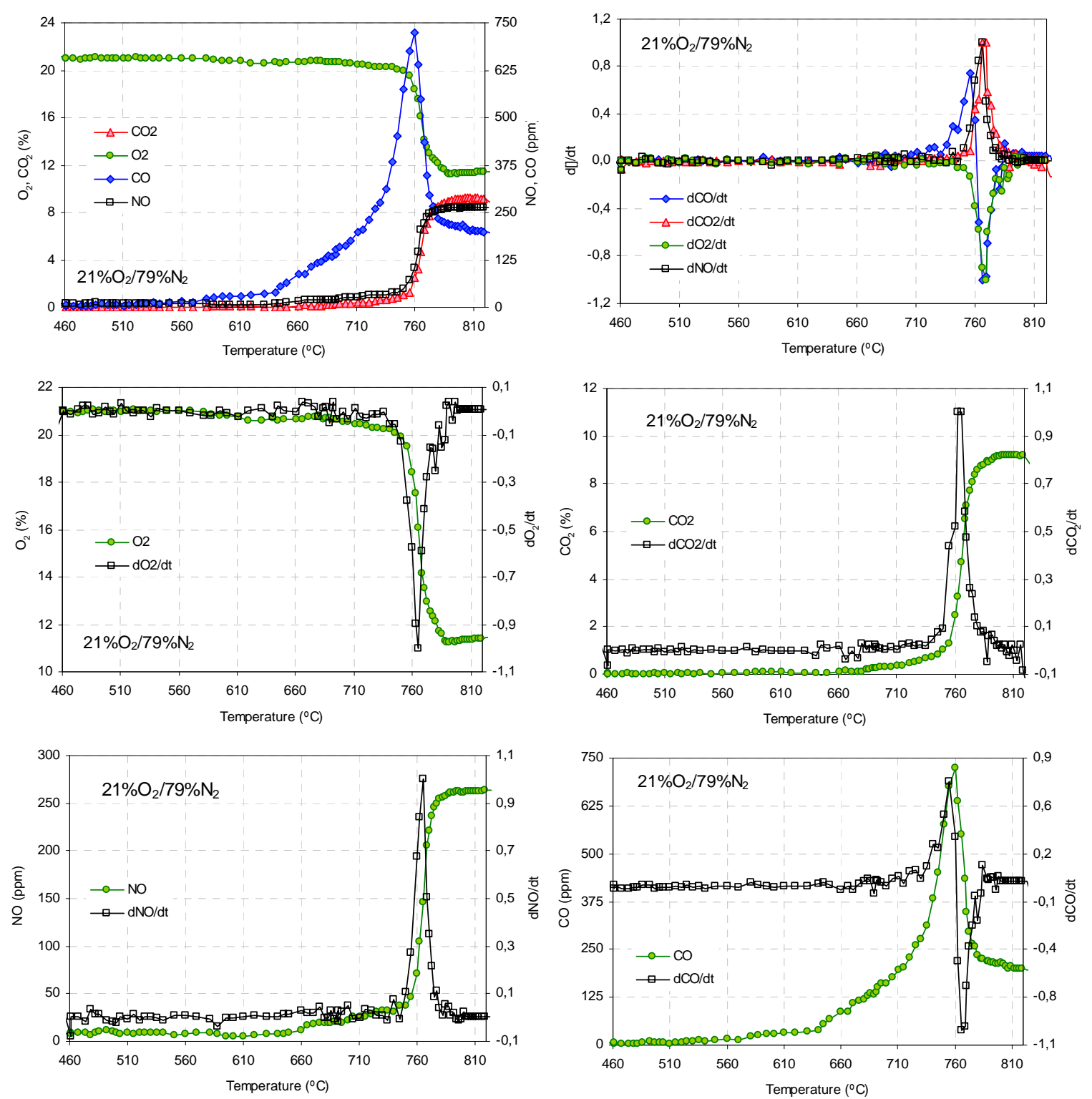

Fig 1. Gas emissions and normalised derivative curves of gas concentration during ignition tests in air for anthracite coal AC. 

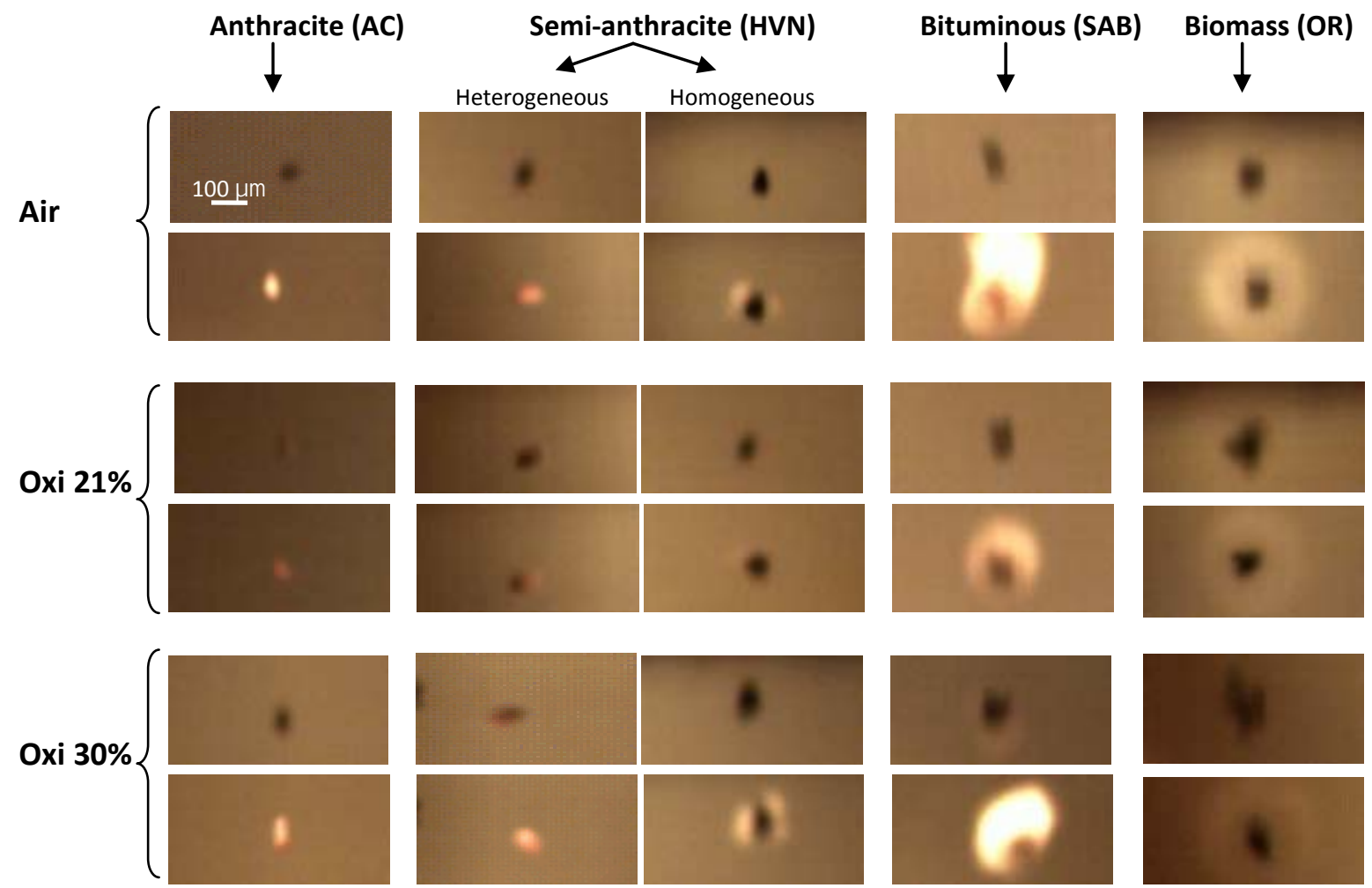

Fig 2. High-speed, high-magnification cinematographic images of single particles (75$150 \mu \mathrm{m}$ ) of various coals (anthracite $\mathrm{AC}$, semi-anthracite $\mathrm{HVN}$, and two bituminous $\mathrm{SAB}$ and $\mathrm{BA}$ ) and a biomass (olive residue $\mathrm{OR}$ ) in air and in two different simulated oxy-fuel conditions $\left(21 \% \mathrm{O}_{2}-79 \mathrm{CO}_{2}\right.$ and $\left.30 \% \mathrm{O}_{2}-70 \% \mathrm{CO}_{2}\right)$. In each case, a particle is shown prior and after ignition takes place. Different coal ranks experience different ignition modes. 

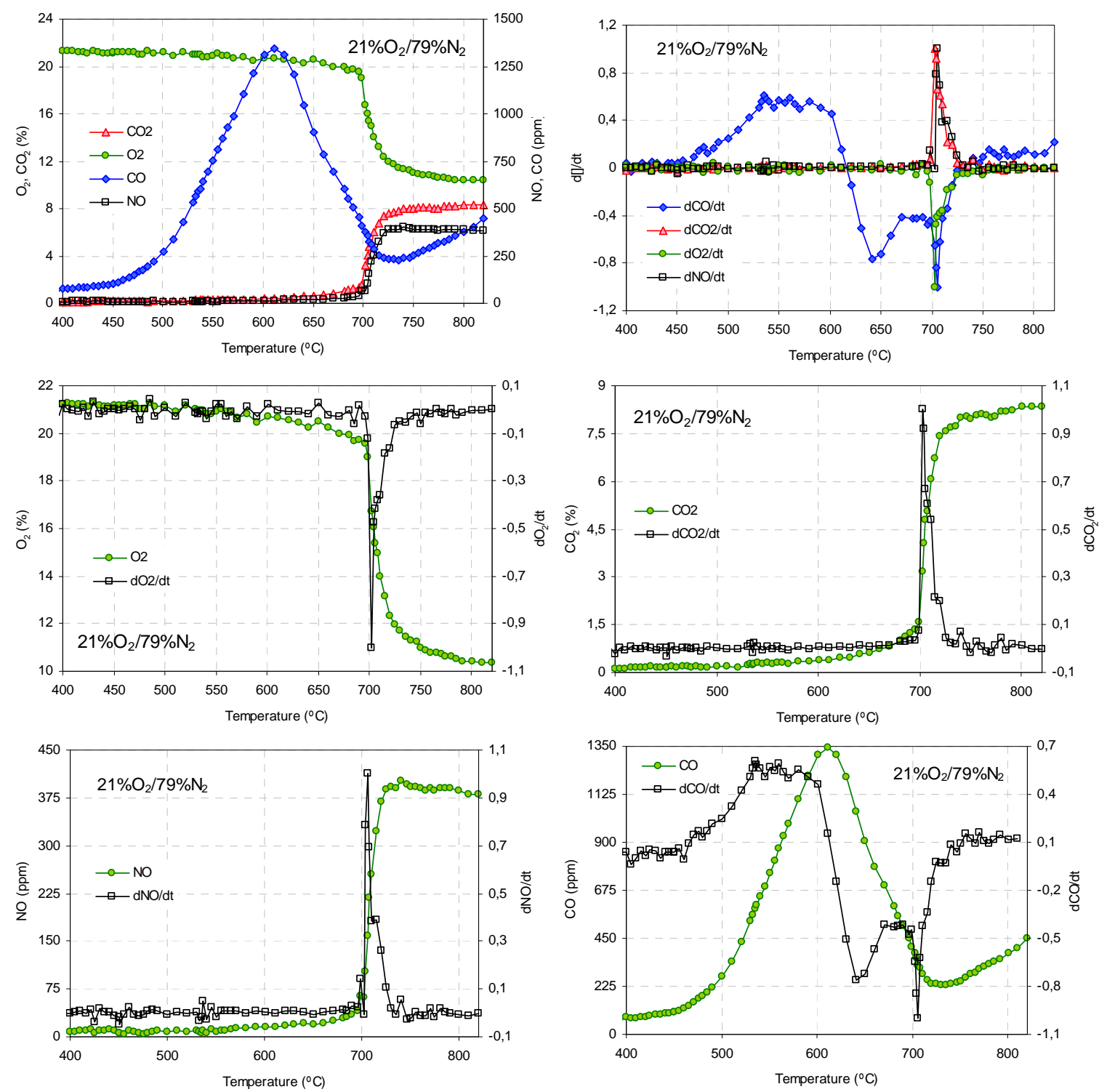

Fig 3. Gas emissions and normalised derivative curves of gas concentration during ignition tests in air for semi-anthracite coal HVN. 

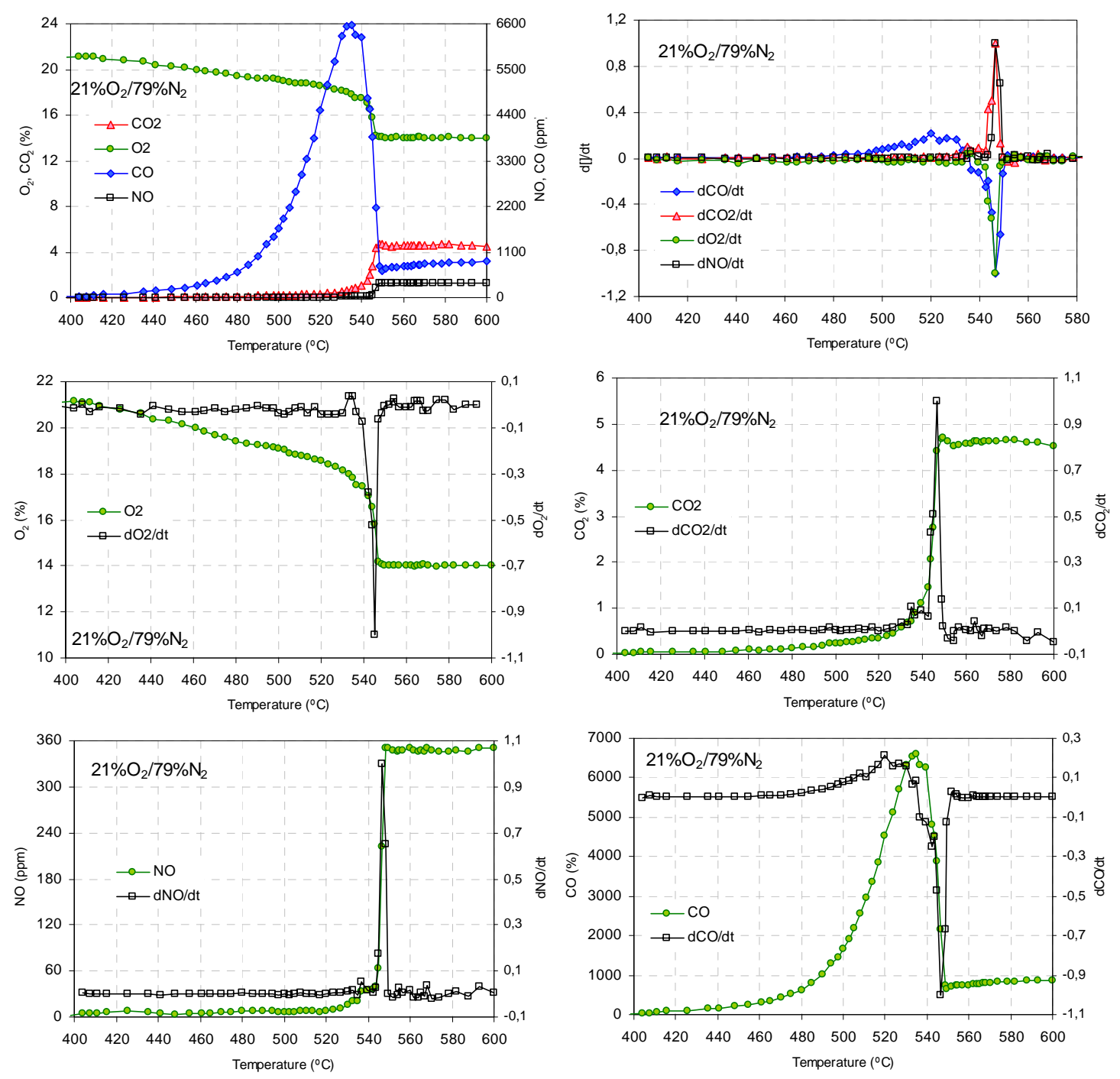

Fig 4. Gas emissions and normalised derivative curves of gas concentration during ignition tests in air for bituminous coal SAB. 

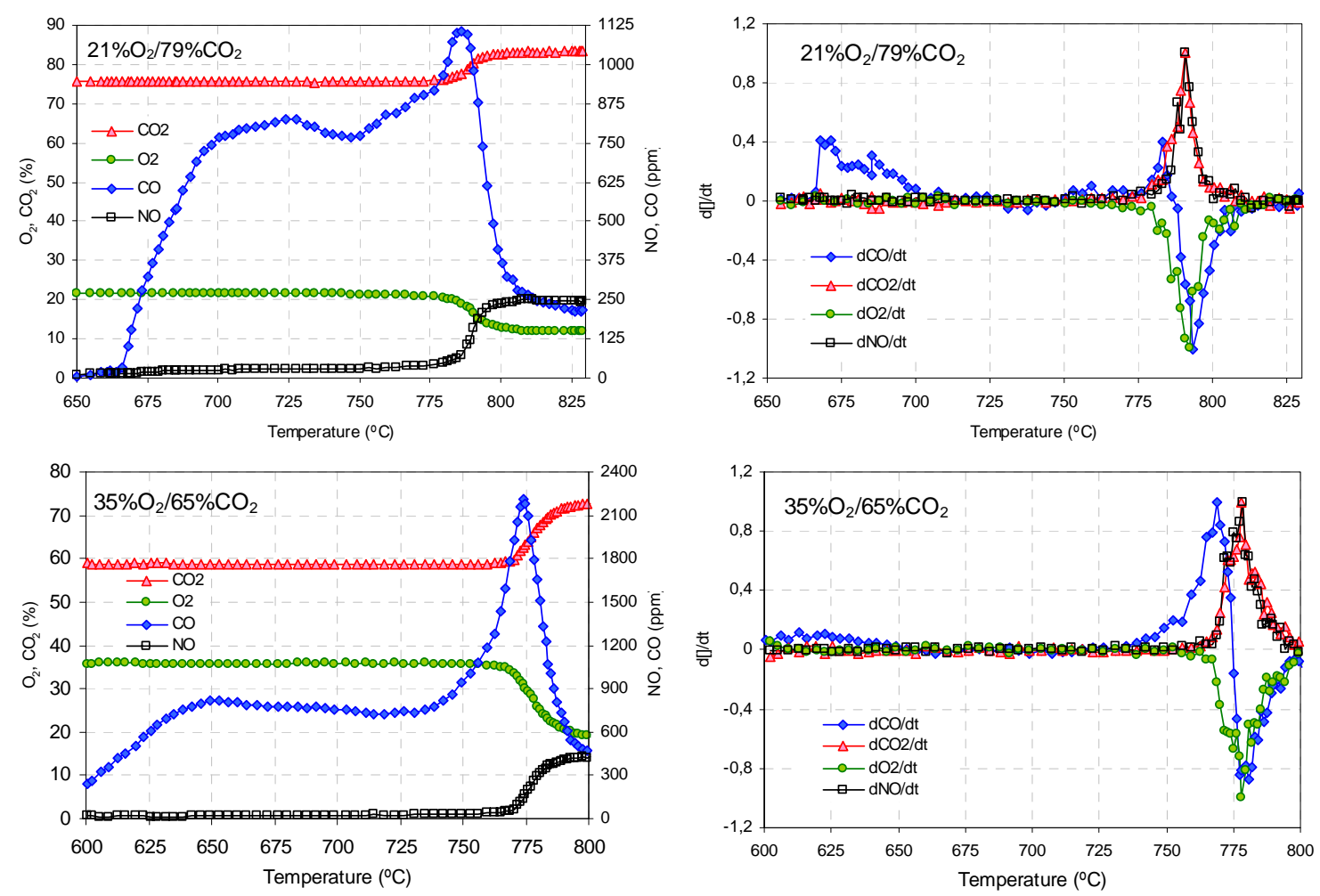

Fig 5. Gas emissions and normalised derivative curves of gas concentration during ignition tests in oxy-firing conditions for anthracite coal AC. 

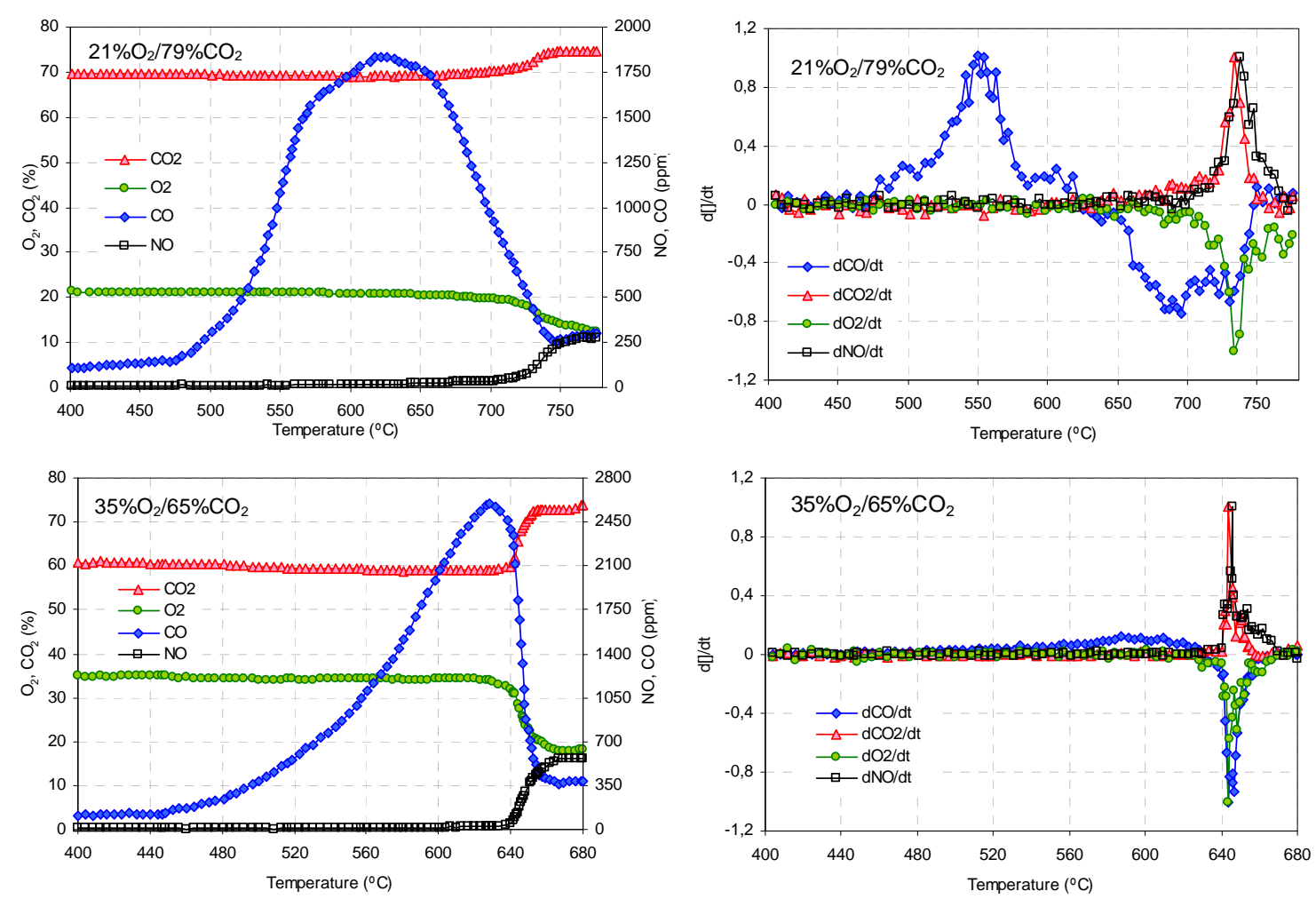

Fig 6. Gas emissions and normalised derivative curves of gas concentration during ignition tests in oxy-firing conditions for semi-anthracite coal HVN. 

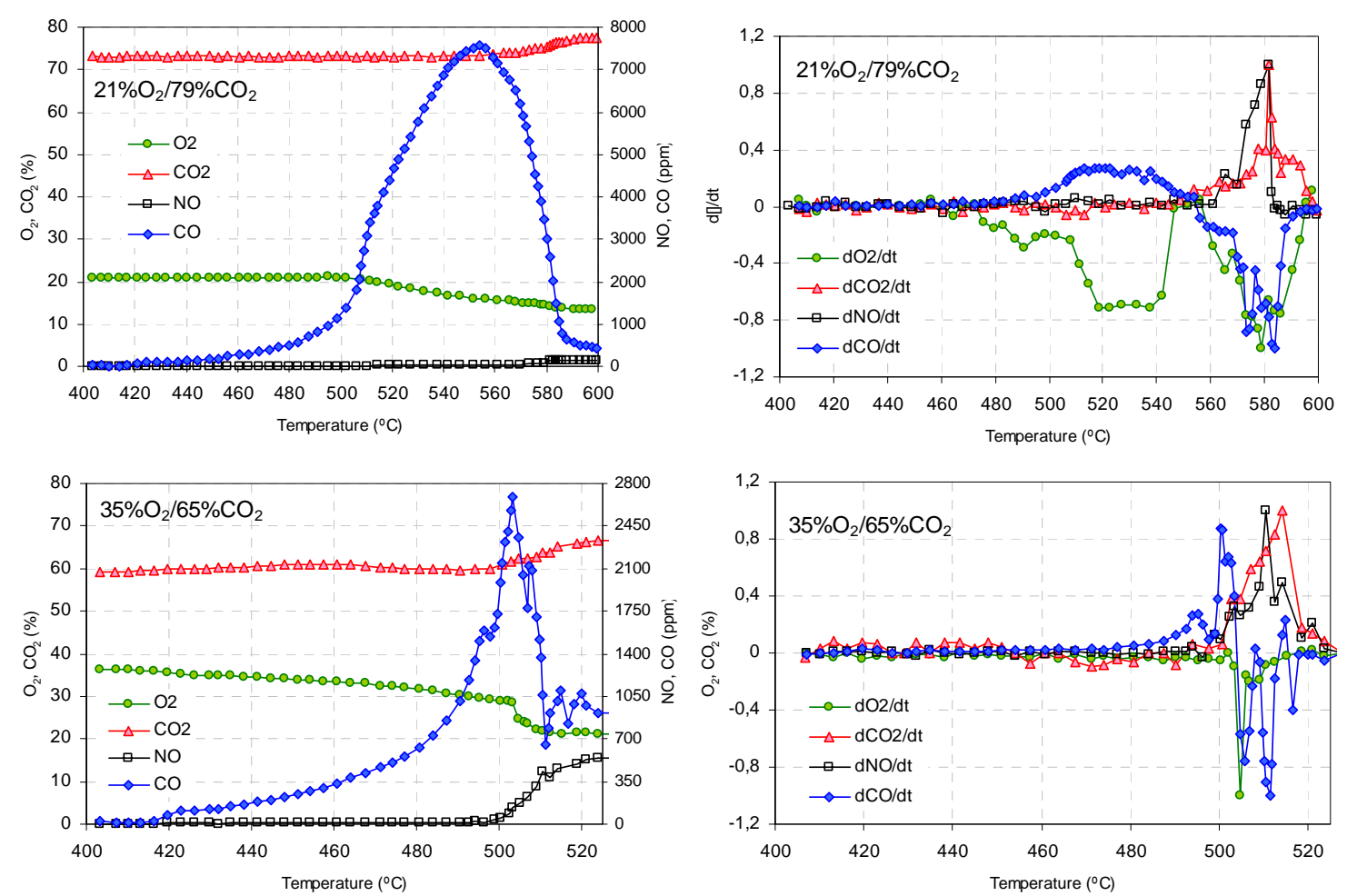

Fig 7. Gas emissions and normalised derivative curves of gas concentration during ignition tests in oxy-firing conditions for bituminous coal SAB. 

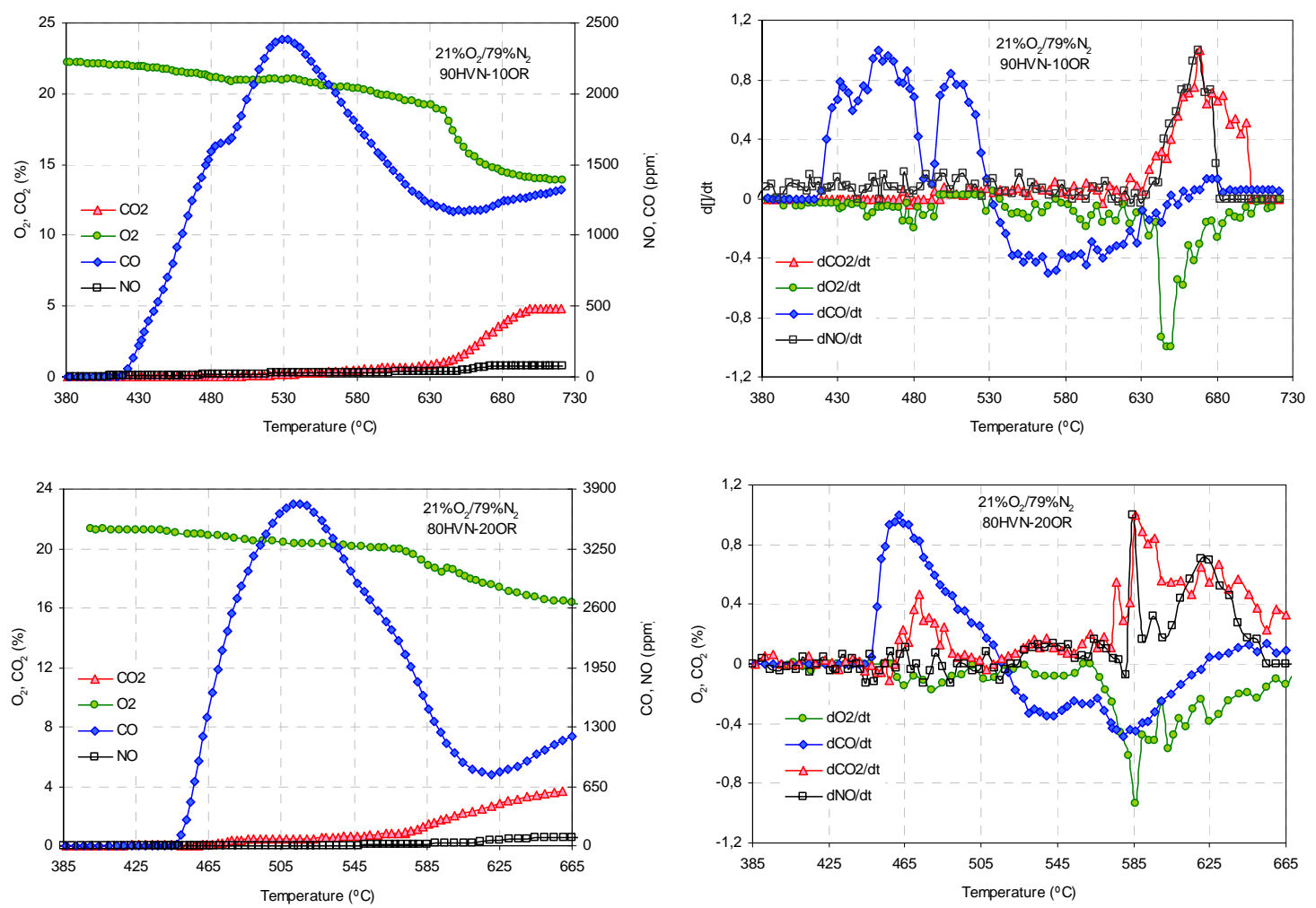

Fig 8. Gas emissions and normalised derivative curves of gas concentration during ignition tests in air-firing conditions for blends HVN-OR. 

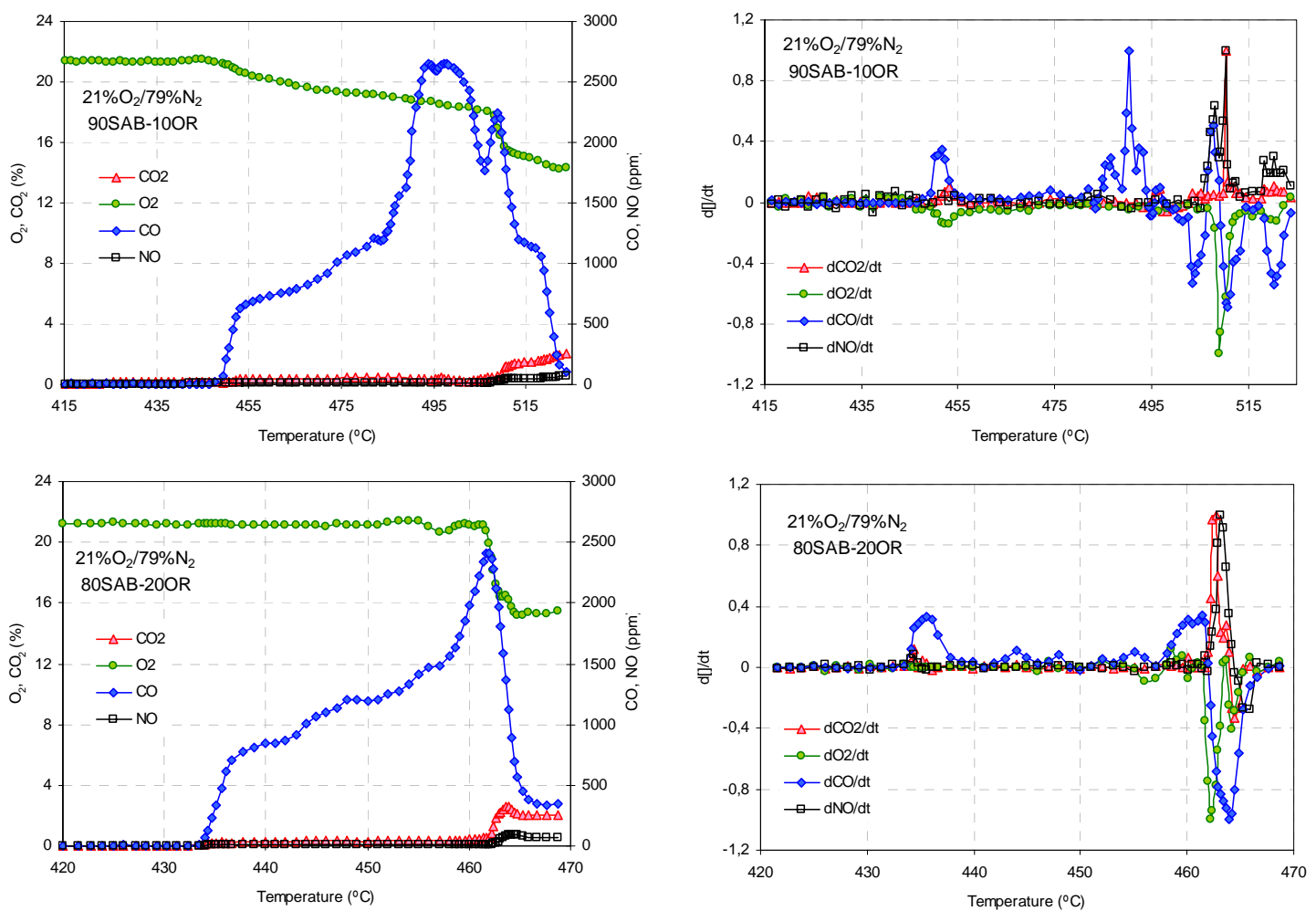

Fig 9. Gas emissions and normalised derivative curves of gas concentration during ignition tests in air-firing conditions for blends SAB-OR. 

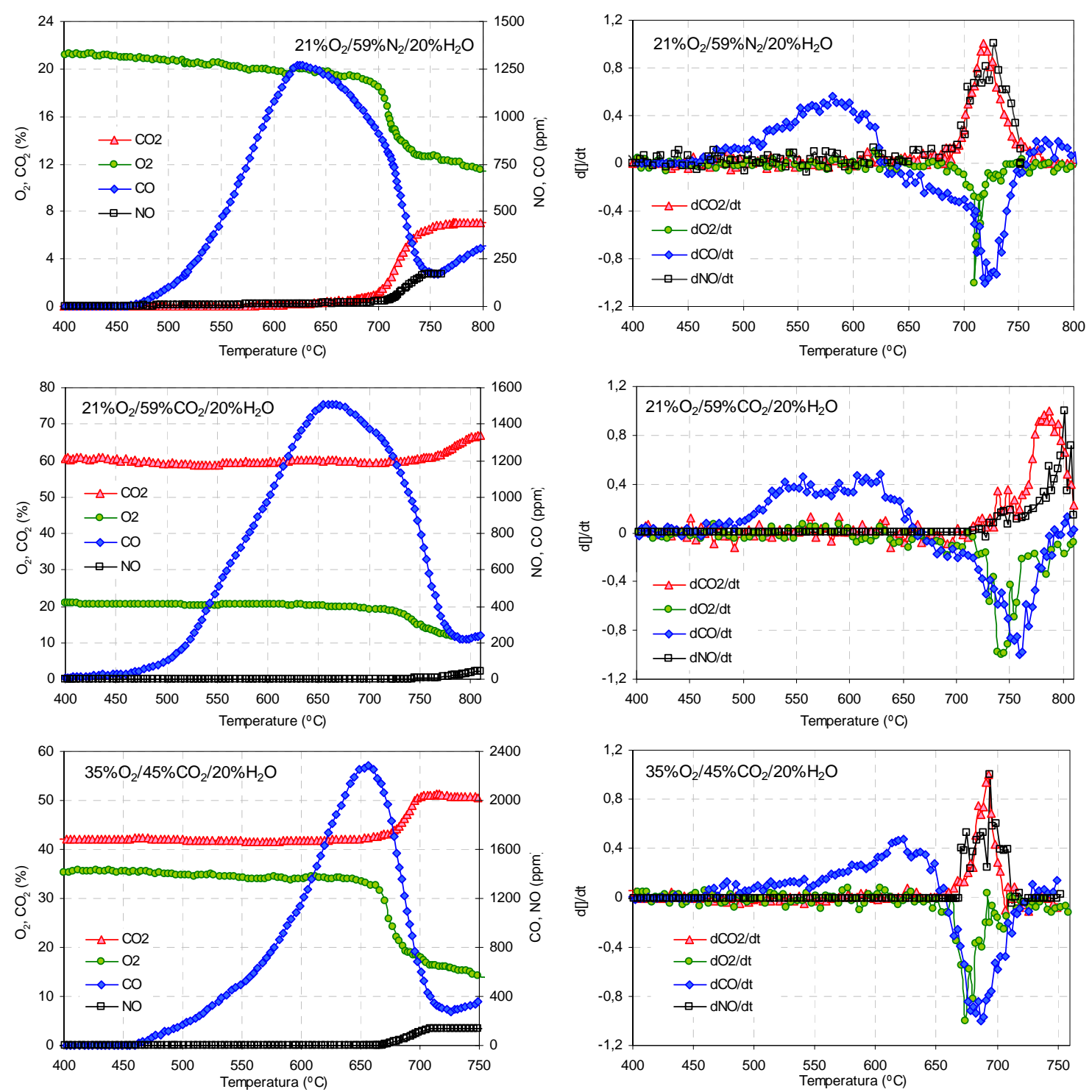

Fig 10. Gas emissions and normalised derivative curves of gas concentration during ignition tests for semi-anthracite coal $\mathrm{HVN}$ in air and $\mathrm{O}_{2} / \mathrm{CO}_{2}\left(21-35 \% \mathrm{O}_{2}\right)$ with $20 \%$ steam addition (the $\mathrm{H}_{2} \mathrm{O}_{(\mathrm{v})}$ is added as a substitute of $\mathrm{N}_{2}$ or $\mathrm{CO}_{2}$ ). 